\title{
FRONTEIRA: A DEGRADAÇÃO DO OUTRO NOS CONFINS DO HUMANO
}

\author{
FRONTIER: THE DEGRADATION OF THE OTHER IN THE HUMAN \\ CONNECTIONS
}

MARTINS, José de Souza. Fronteira: a degradação do Outro nos confins do humano. São Paulo: Contexto, 2019.

\section{Patrícia Rodrigues da Silva ${ }^{1}$}

A obra analisa aspectos da construção do conceito de fronteira, para além do aspecto geográfico, considerando suas implicações históricas, sociológicas e econômicas. José de Souza Martins discorre sobre as distinções entre as categorias frente pioneira e frente de expansão, nos territórios ocupados por povos indígenas na região da Amazônia brasileira.

Nesse ponto, vale uma consideração sobre a diferenciação entre frente pioneira e frente de expansão. O esforço sistemático de compreensão das relações de trabalho pela ótica do capitalismo e, eventualmente, orientador da natureza das atividades humanas, introduz uma concepção econômica ao conceito de frente pioneira. Entende-se como frente pioneira o avanço da unidade de produção capitalista e, em contraposição, a frente de expansão que afasta a ideia do espaço feito através da mediação do capital como, por exemplo, a ocupação indígena.

Considerando um cenário altamente conflitivo de humanidades, muito embora houvesse a idealização do humano idílico herdado da tradição filosófica e das idealizações dos humanistas, a fronteira é, sobretudo, um cenário de intolerância, ambição e morte. O discurso ensejador desse cenário altamente conflitivo perpassa as diferentes aspirações dos diversos grupos étnicos, e na concepção de fronteira como ponto limite de territórios que se redefinem continuamente.

Essencialmente interdisciplinar, a obra apresenta aportes teóricos sociológicos, antropológicos e históricos, que abarca questionamentos sobre a sociedade em que vivemos e a própria condição humana. A pesquisa empírica deriva de 30 anos de investigação nas frentes pioneiras do Brasil, em diferentes ocasiões e em diferentes pontos da região amazônica.

$\mathrm{O}$ questionamento fundamenta-se no caráter múltiplo da fronteira e na necessidade de deslocar o olhar racional e simplificado de um lugar que viabiliza existências: fronteira da civilização, fronteira espacial, fronteira de culturas e percepções de mundo, fronteira de etnias, fronteira da história e da historicidade do homem e, sobretudo, fronteira do humano.

A importância do tema reside na visibilidade de vivências que foram vítimas do processo

1 Pontifícia Universidade Católica de Goiás (PUC Goiás)E-mail: patricia.silva123@hotmail.com 
de expansão e luta pela fronteira. O autor assume abertamente o lado da vítima, por compreender ser a narrativa moralmente mais justa. Manifesto não panfletário de suas tragédias e lutas, que denuncia as relações de violência que alcançam certas populações. Assim, para além da devastação florestal na Amazônia, a obra trata-se da invisibilidade da devastação humana que ocorre na frente pioneira do país.

A formação da identidade do povo brasileiro se constrói, também, nos próprios conflitos históricos. O caráter político da fronteira, não raro, permeado por massacres e assassinatos de índios e de trabalhadores da frente de expansão, é construído através de invasão e espoliação branca e capitalista de territórios - processo intensificado pela modalidade de desenvolvimento capitalista vigente na sociedade.

A discussão inicia-se com a análise dos raptos na situação de fronteira, com enfoque na captura de mulheres e crianças nas fronteiras étnicas do Brasil. Analisa o rapto de pessoa como uma espécie de morte cultural e social, feita pelos grupos tribais entre si, pelas comunidades indígenas e dos brancos em relação aos índios. Não reconhecer humanidade no outro, efetiva-se a ausência de alteridade.

Isso não significa dizer, no entanto, que o rapto assuma o mesmo significado e implicações nos distintos grupos. O rapto deve, necessariamente, prescindir da situação de fronteira que decorre do movimento frente de expansão nacional.

Ressalta-se a captura de índios nas primeiras décadas no século XX para sua escravização nos seringais da Amazônia, submetidos à peonagem e escravidão por dívida - período histórico que coincide com as primeiras tentativas de ocupação econômica da região, embora a região estivesse ocupada pela comunidade indígena e populações tradicionais. Muito embora a escravidão indígena juridicamente se torne proibida, o rapto de índios ganha uma nova faceta, a da genocida limpeza de áreas cobiçadas e invadidas pelos brancos para abertura de novas fazendas.

Martins reafirma a retórica marxista do escravismo como vetor do processo de organização do capital, tornando o outro (raptado) como sujeito de conflitos sociológicos e culturais.

A literatura especializada acerca do tema da reprodução do capital na frente pioneira e o renascimento da escravidão demonstra certo grau de complexidade de conceituação das relações trabalhistas existentes no Brasil. A abordagem adotada perpassa pela demonstração dessas relações com enforque, sobretudo, na escravidão e na peonagem, por serem desatreladas ao conceito de Justiça Econômica e manifestar seus impactos nas relações sociais hodiernas.

É válido supor que tais relações de trabalho não seguem um padrão contratual e juridicamente viável entre empresário e trabalhador. A acumulação capitalista da terra fomenta a dominação patrimonial e é apontada como núcleo do empobrecimento e do acirramento das tensões sociais.

Posteriormente, o autor desloca o olhar narrativo para os ainda mais silenciados pela história: mulheres, crianças, velhos, agregados da casa, dependentes aqueles que vivem de favor. A percepção desses sujeitos da situação de conflito confere um caráter empático na construção da análise da fronteira, feito através da escuta. 
E, por fim, Martins conclui que, mesmo sendo seu posicionamento contrário à mentalidade dominante, a análise da situação de fronteira no Brasil perpassa inequivocamente, a situação do conflito social. A questão demanda sensibilidade crítica, e inaugura o diálogo para se promover mecanismos de autodeterminação de povos subalternos, fomentando as práticas de justiça econômica e social. 